liament have repeatedly confirmed the continuity of the European Union's course for accession, and the fact that in early 2020 it was decided to extend the deadlines for the development of legal instruments establishing models of the European Union's accession to the Convention in the ad hoc group cannot but confirm the perspective of accession at least in the long run.

Key words: European Union, European Convention on Human Rights, accession, Draft agreement, Court of Justice of the European Union, Opinion 2/13.

DOI: $10.36695 / 2219-5521.1 .2020 .75$

УДК 341.45

\title{
в.в. попко
}

Вадим Вікторович Попко, кандидат юридичних наук, доцент, доцент Інституту міжнародних відносин Київського національного університету імені Тараса Шевченка*

ORCID: 0000-0001-8358-7721

\section{НАЦІОНАЛЬНЕ ЗАКОНОДАВСТВО - ДЖЕРЕЛО ТРАНСНАЦІОНАЛЬНОГО КРИМІНАЛЬНОГО ПРАВА}

Постановка проблеми. 3'ясування системи джерел транснаціонального кримінального права є принциповим питанням для дослідження транснаціонального кримінального права та має не тільки наукове, теоретичне, а й велике практичне значення. Виявлення закономірностей їх розвитку сприяє розумінню природи транснаціонального кримінального права, тенденцій розвитку, формування ієрархії джерел, юридичної сили різних нормативно-правових актів, їх застосування та ін. Визнання національного законодавства джерелом транснаціонального кримінального права є важливим питанням з огляду на головну концептуальну особливість транснаціонального кримінального права: взаємодія транснаціонального (міжнародного) та внутрішньодержавного (національного) кримінального права. Транснаціональне кримінальне право як підгалузь міжнародного кримінального права входить у систему міжнародного права, базується на її принципах і тісно пов'язане $з$ національним кримінальним правом.

Метою статті $є$ вивчення системи джерел транснаціонального кримінального права, їх класифікації, місця національного законодавства в якості джерела (форми) права у цій системі.

Аналіз останніх досліджень. У доктрині міжнародного кримінального права проблематика джерел (форм) права ставилась і вивчалась тією чи іншою мірою в певних аспектах неодноразово, проте становлення й розвиток транснаціонального кримінального права потребує з'ясування їх видів 3 огляду на необхідність обгрунтування концепції транснаціонального кримінального права, а також вивчення емпіричного матеріалу: міжнародно-правових актів та законодавства різних держав.

Вагоме значення для даного дослідження мають: загальнотеоретичні праці вітчизняних і зарубіжних вчених, доктринальні напрацювання сучасного міжнародного права, концепції міжнародного кримінального права, проте особливий інтерес становлять розробки вчених безпосередньо в теорії джерел права (Ж.-Л. Бержель, М.I. Козюбра, Л.А. Луць, М.М. Марченко, Н.М. Онищенко, Н.М. Пархоменко) та зокрема в теорії міжнародного права. У їх працях ми знаходимо теоретико-концептуальний підхід до розуміння поняття джерело права з позицій широкого підходу та у формально-юридичному розумінні. Розгорнутий аналіз джерел міжнародного права дається в дисертаційному дослідженні О.В. Київець ${ }^{1}$, яка виокремлює загальні принципи права як основу сучасного міжнародного правопорядку, міжнародний звичай як основну форму закріплення універсальних міжнародних зобов'язань та міжнародний договір, а також некласичні джерела міжнародного права - односторонні акти суб'єктів міжнародного права та акти міжнародних інституцій. Крім того, останнім часом тематика джерел транснаціонального кримінального права активно досліджується вченими у контексті загальної теорії міжнародного кримінального права, зокрема, це роботи таких українських та зарубіжних науковців, як Дж. Альбанезе, К. Амбос, Н. Бойстер, А. Боссард, М.В. Буроменський, Г. Верле, В.В. Голина, В.Н. Денисов, Н.В. Дрьомін, Г.П. Жаровська, Н.А. Зелінська, А. Кассезе, О.В. Київець, Л.А. Луць, Т.Л. Сироїд, Дж. Шварценбергер, М. Шоу.

Виклад основного матеріалу. Система джерел права не є усталеною назавжди, вона змінюється й відбиває розвиток права в цілому. Професор М.І. Козюбра звертає увагу на тенденції сучасного розвитку джерел права з позицій широкого підходу ${ }^{2}$, про «нові» види джерел права пише професор М.В. Буроменський ${ }^{3}$, професор Н.М. Пархоменко зазначає, що окремі положення праць вчених, які розробляли теорію джерел права, залишаються актуальними, інші потребують перегляду4. Щодо визначення системи джерел права, важливою є позиція професора Л.А. Луць, яка обгрунтовує її наступним: поняття «система джерел права» відображає «стан розформалізованості правової системи за рахунок урізноманітнення зовнішніх форм (джерел) права, а також необхідності їх взаємоузгодження у межах єдиної системи нормативних регуляторів».

\section{(C) В.В. Попко, 2020}

* Vadym Popko, Ph.D. in Law, Associate professor, Associate professor of the Institute of International Relations of Taras Shevchenko National University of Kyiv 
Аналіз правових систем світу свідчить про значну багатоманітність зовнішніх форм (джерел) права, підкреслює Л.А. Луць. Найбільш використовуваними джерелами права в різних правових системах є нормативноправовий акт, нормативно-правовий договір, нормативно-правовий прецедент, правовий звичай, принципи права. У деяких правових системах як зовнішні форми (джерела) права використовуються релігійні джерела, а також правова доктрина. При цьому в кожній національній чи міждержавній правовій системі формується специфічна, саме цією правовою системою витребувана система джерел права. Це дає змогу говорити про особливості кожної з таких систем джерел права чи видові або ж типологічні їх особливості. 3 позицій загальної теорії права система джерел права є зовнішньою формою системи права, тобто вони співвідносяться як форма і зміст. Система джерел права має суб'єктивний характер, оскільки її формування залежить від суб'єктів правотворення. Від якісної та ефективної діяльності суб'єктів правотворення залежить і динамічний характер системи джерел права, здатність їі реагування на потреби суспільства, зокрема щодо необхідності впорядкування відносин між суб'єктами за допомогою норм права. Тому це свідчить про можливість використання системи джерел права як специфічної нормативно-правової організації, необхідної для правового регулювання в будь-якому суспільстві» 5 . Отже, система джерел права $є$ комплексом взаємопов'язаних та взаємоузгоджених нормативно-правових приписів, які об'єктивовані у відповідних зовнішніх формах і утворюють необхідну нормативно-правову основу для забезпечення правового регулювання будь-яких відносин.

Своєрідна система джерел права склалась і в міжнародному кримінальному праві. Посилання на застосовне право містяться в багатьох міжнародно-правових актах, проте ні один із міжнародних документів не містить вичерпного переліку джерел права. Найбільш повно даний перелік вказано у ст. 38 Cmamymy Miжнародного суду $O O H$, на яку посилаються більшість авторів та яка широко визнається в юриспруденції в якості переліку джерел міжнародного права. У цій статті зазначено, що Суд застосовує: «а) міжнародні конвенції як загальні, так і спеціальні, що встановлюють правила, безперечно визнані державами, які є сторонами спору; b) міжнародний звичай як доказ загальної практики, визнаної в якості правової норми; с) загальні принципи права, визнані цивілізованими націями; d) із застереженням, вказаним у ст. 59, судові рішення і доктрини найбільш кваліфікованих фахівців з публічного права різних націй у якості допоміжного засобу для визначення правових норм» ${ }^{6}$. Застереження ст. 59 стосуються того, що «рішення Суду є обов’язковим лише для сторін, що беруть участь у справі, і лише по даній справі».

Розгорнутий аналіз джерел міжнародного права дає професор М.В. Буроменський, який також зазначає дискусійний характер переліку джерел у зв’язку з появою «нових» видів та підкреслює принципове значення визначення поняття та видів джерел для міжнародного права. М.В. Буроменський акцентує увагу на тому, що метою ст. 38 Статуту МС ООН «було не надання переліку всіх джерел МП, а визначення джерел, які Суд застосовує у своїй практиці», до того ж перелік джерел, наведений у цій статті, є загальновизнаним і «як такий не може бути скороченим»7.

Слушне зауваження робить і професор Н.А. Зелінська, яка пише, що перелік джерел згідно зі ст. 38 (1) Статуту МС ООН є «початковим орієнтиром для визначення системи джерел міжнародного кримінального права» ${ }^{8}$. Слід додати, що такий характер мають й інші загальні джерела міжнародного права, зокрема основоположне значення для формування джерел транснаціонального кримінального права мають: Загальна декларація прав людини, Міжнародний пакт про громадянські й політичні права, Конвенція РС про захист прав людини і основоположних свобод, Статут ООН. Усі вони є частиною міжнародного права і можуть застосовуватися на цій підставі як загальні джерела міжнародного права.

3 плином часу характер норм міжнародного права значно змінився порівняно з 1945 р., відколи було прийнято Статут Міжнародного суду й сам Статут ООН. Про необхідність осучасненого підходу до характеристики норм міжнародного права писав ще у 60-х рр. ХХ ст. В. Фрідман у праці «Мінлива структура міжнародного права ${ }^{9}$, оскільки з'явилася нова внутрішня динаміка міжнародного права, що привела до активного співробітництва як на світовому, так і на регіональному рівнях, під впливом зовнішніх чинників - зміною геополітичних реалій. У наш час зміст ст. 38 , який майже дослівно повторює аналогічну норму Статуту Постійної палати Міжнародного правосуддя від 16 грудня 1920 р., створеної після Першої світової війни Лігою Націй, піддається обгрунтованій критиці як застарілий і такий, що не відповідає вимогам сьогодення. Положення цієї норми зазвичай сприймається як відправна точка при розгляді джерел міжнародного права.

Фундаментальною основою транснаціонального кримінального права визнається міжнародне кримінальне права, його принципи та джерела, серед яких важливе місце займає Римський статут Міжнародного кримінального права, ухвалений 17 липня 1998 року10. У Римському Статуті перелік джерел права більш конкретизований і у ст. 21 Статуту «Застосовне право» зазначено, що Суд застосовує: «а) по-перше, названий Статут, Елементи злочинів і свої Правила процедури і доказування; b) по-друге, у відповідних випадках, застосовні міжнародні договори, принципи і норми міжнародного права, включаючи загальновизнані принципи міжнародного права збройних конфліктів; с) якщо це неможливо, Суд застосовує загальні принципи права, взяті ним із національних законів правових систем світу, включаючи, відповідно, національні закони держав, які за звичайних обставин здійснювали б юрисдикцію відносно даного злочину, при умові, що ці принципи не $\epsilon$ несумісними з названим Статутом і з міжнародним правом і міжнародно визнаними нормами і стандартами». На сьогоднішній день Статут МКС, зазначає Г. Верле, «є центральним документом міжнародного кримінального права. Він заклав правову основу Міжнародного кримінального суду і встановив для нього новий тип процесуального права. Статут МКС також став важливим етапом у розвитку матеріального міжнародного кримінального права» ${ }^{11}$.

Сказане повною мірою стосується і джерел транснаціонального кримінального права та випливає 3 тлумачення джерела права в широкому розумінні. 3 позицій широкого підходу, характеризуючи систему джерел 
транснаціонального кримінального права, слід виходити 3 того, що «міжнародна нормативна система як сукупність суб'єктів та інститутів сучасного міжнародного права має цілісний характер» ${ }^{12}$. Щодо формально-юридичного підходу, то слід зазначити, що система джерел транснаціонального кримінального права не повністю збігається з системою джерел міжнародного права й має свої особливості, які полягають, як зазначає I.I. Лукашук, «у характері взаємодії цих джерел» ${ }^{13}$. У транснаціональному кримінальному праві зливається «універсальна властивість національного і міжнародного права - правове й індивідуальне регулювання суспільних відносин як парних категорій» ${ }^{14}$.

Виходячи $з$ цих концептуальних засад джерел права в системі джерел транснаціонального кримінального права, виокремимо дві основні групи: універсальні (загальні принципи права, конвенції, міжнародні звичаєві норми) та допоміжні джерела (судові рішення, судова практика, доктрини, норми національного законодавства, рішення внутрішньодержавних судів). Безперечно, основним джерелом транснаціонального кримінального права слід вважати конвенції (універсальні, регіональні, антикримінальні), що підкреслюється багатьма вченими (Н. Бойстер, М.В. Буроменський, О.В. Буткевич, Н.А. Зелінська, В.В. Мицик, В.П. Панов). Зазначимо, що на формування джерел транснаціонального кримінального права впливають численні міжнародно-правові акти (декларації, заяви, звернення, рекомендації), що приймаються міжнародними організаціями та їх органами (ООН, Рада Європи, Євросоюз, Інтерпол, Європол, IКАО, IMO, МОМ, МАГАТЄ).

У системі джерел транснаціонального кримінального права особливе місце посідає національне законодавство держав. Матеріальним джерелом національних правових актів є діяльність правотворчих органів, а міжнародних договорів - угоди держав, міжнародних організацій - правомочних суб'єктів міжнародного права. У доктрині сформувалось кілька позицій щодо визнання національного законодавства джерелом міжнародного кримінального права. Існує позиція заперечення визнання норм національних законів у такій якості (В.П. Панов ${ }^{15}$ ). Авторитетною є позиція визнання провідної ролі національного права при формуванні міжнародного кримінального права (I.I. Лукашук ${ }^{16}$, Н.О. Ушаков ${ }^{17}$ ), зокрема норми щодо злочинності й караності діяння, співучасті, крайньої необхідності, видах покарання тощо сприйняті міжнародним кримінальним правом із національних правових систем. О.Г. Кибальник та І.Г. Соломоненко звертають увагу на вагомий вплив, що здійснює національний закон чи національне правозастосування на формування міжнародноправового акта, проте не йдеться про їх обов'язкову силу: «в силу відсутності імперативного характеру й формально визначеної юридичної сили - національне законодавство і рішення внутрішньодержавних судів навряд чи можна віднести до імперативних джерел міжнародного кримінального права у строго юридичному розумінні останніх» ${ }^{18}$. Низка авторів відводять національному кримінальному праву й рішенням внутрішньодержавного кримінального суду роль допоміжних (другорядних) джерел (І.П. Бліщенко, Ж. Доріа19). Сучасні дослідники наполягають на визнанні національних кримінально-правових норм самостійним джерелом міжнародного кримінального права (Л.В. Іногамова-Хегай $\left.{ }^{20}\right)$.

Важливою є позиція професора М.I. Козюбри, який пише, що «хоч національне право безпосередньо не регулює міжнародні відносини, це не означає що його норми, як і національні правові системи в цілому, не впливають на міжнародне право і міжнародні правові системи» 21 . Форми такого впливу на транснаціональне кримінальне право можуть бути різноманітними і виявлятися у визначенні національної кримінальної політики; при підписанні, ратифікації чи денонсації міжнародних конвенцій; у визначенні порядку утворення та функціонування виключних економічних зон, зон вільної торгівлі; при наданні правової допомоги іноземним державам та міжнародним організаціям тощо. Національні закони та інші нормативно-правові акти можуть стимулювати ухвалення нових чи внесення відповідних змін до інших міжнародно-правових документів, що в свою чергу сприяє поглибленню співробітництва держав у сфері протидії міжнародній злочинності в реалізації спільних інтересів світового співтовариства на основі загальних, визнаних цивілізованими націями, принципів права.

У літературі також зазначається роль судової практики національних судів: «рішення національних судів можуть відігравати двояку роль щодо міжнародного звичаєвого права: не тільки як державна практика, але також і як засіб для визначення норм міжнародного звичаєвого права» 22 . На двоїсту роль рішень національних судів звертає увагу й Г. Верле, який пише, що «по-перше, як форми відображення opinio juris і практики держав, вони можуть підтверджувати чи формувати звичаєве право і робити внесок у формування загальних принципів права. По-друге, рішення національних судів можуть служити в якості допоміжних засобів визнання права, що допомагають визначати зміст норм міжнародного кримінального права»23. Особливо важливими для формування норм міжнародного кримінального права, й зокрема транснаціонального кримінального права, $є$ рішення у кримінальних справах у національних судах, у ході яких безпосередньо застосовується міжнародне (транснаціональне) кримінальне право. Таких справ небагато, проте ця обставина підтверджує й збільшує їх цінність.

Зазначимо, що між усталеними джерелами міжнародного кримінального права (конвенції, звичаї, судова практика) й національними законами існує тісний зв'язок. Національні органи, що здійснюють кримінальне переслідування за транснаціональні злочини, а також у процесі взаємодії з органами іноземних держав та міжнародними органами, застосовують внутрішнє право, яке має відповідати нормам міжнародного права та міжнародного кримінального права, або застосовувати норми цих галузей безпосередньо. При ратифікації Конвенції ООН проти транснаціональної організованої злочинності в Законі України зазначено, що «Конвенція застосовуватиметься тільки за умови дотримання конституційних принципів і фундаментальних засад правової системи України» (п. 1)24. Застосування національними органами міжнародного права зумовлено внутрішньодержавною системою, в якій заснований і діє судовий орган. Компетенція національного суду застосовувати міжнародно-правові норми базується на відповідних положеннях внутрішнього права держави. Національні системи права доповнюються положеннями міжнародного кримінального права, їх цілі й 
завдання збігаються: переслідування й покарання винних осіб у скоєнні злочину, попередження злочинів, усунення причин і умов вчинення злочину. Зазвичай, норми, закріплені в міжнародних договорах після їх ратифікації національним законодавством, стають його частиною.

Слід зазначити, що у випадку вчинення транснаціонального злочину рішення (вирок) виноситься на підставі національного законодавства. У випадку з міжнародними злочинами міжнародний трибунал виносить вирок безпосередньо на підставі міжнародного права, причому національні суди можуть це робити як на підставі міжнародного, так і внутрішнього права. Національні суди застосовують норми кримінального права із застереженнями. До їх числа належать, зокрема: трансформація договірних норм у внутрішнє кримінальне законодавство; ратифікація та опублікування договорів згідно зі встановленими у законодавствах держав правилами; відповідність договорів загальновизнаним принципам та нормам міжнародного права; точність і конкретність міжнародних договорів; урахування їх застосування національними судами. У практиці судів України допускається застосування судами норм міжнародних договорів після їх ратифікації та опублікування в офіційних джерелах. Проте в судовій практиці пряме застосування норм міжнародного кримінального права при винесенні рішень у кримінальних справах щодо транснаціональних злочинів зустрічається не часто. У таких випадках суди й надалі будуть керуватися національним законодавством, у яке трансформуються норми транснаціонального кримінального права.

Низка положень транснаціонального кримінального права сформульована у правових актах з урахуванням особливостей внутрішньодержавного права, зокрема поняття посадової особи, організованих злочинних груп, форм вини, віку, з досягненням якого можлива кримінальна відповідальність особи тощо, по-різному визначаються у національних законах. У зв'язку з цим у міжнародно-правових актах існують застереження. Наприклад, у Конвенції ООН про боротьбу проти незаконного обігу наркотичних засобів і психотропних речовин 1988 р. встановлено: «З урахуванням своїх конституційних положень і основних принципів своєї правової системи кожна Сторона вживає такі заходи, які можуть бути потрібні, для того, щоб визнати правопорушеннями згідно зі своїм законодавством, коли вони вчиняються навмисно, зберігання, придбання або культивування будь-якого наркотичного засобу або психотропної речовини для особистого споживання на порушення положень Конвенції 1951 року, Конвенції 1961 року з поправками або Конвенції 1971 року» (ст. 3 п. 2) 25 . Так, кримінальне законодавство Нідерландів не передбачає як злочин придбання наркотичних засобів для особистого споживання. У Конвенції ООН проти транснаціональної організованої злочинності 2000 р. закріплено: «Для цілей пункту 1 цієї статті і статті 9 цієї Конвенції “публічною посадовою особою” є публічна посадова особа або особа, що надає будь-яку публічну послугу, як це визначається внутрішнім законодавством Держави-учасниці, в якій ця особа виконує такі функції, і як це застосовується в кримінальному законодавстві цієї Держави-учасниці» (ст. 8 п. 4) 26.

Таким чином, враховуючи особливості національних правових систем, транснаціональне кримінальне право передбачає, що низку кримінально-правових понять національні органи застосовують згідно зі своїми правовими принципами. Звичайно, що врахування особливостей внутрішнього права не повинно суперечити загальновизнаним міжнародним принципам і нормам.

Щодо визнання норм внутрішньодержавного законодавства джерелами транснаціонального кримінального права посилань у міжнародно-правових актах небагато. Наприклад, у Конвенції по морському праву 1982 р. та Женевській конвенції про територіальне море та прилеглу зону 1958 р. встановлено, що юрисдикція прибережної держави поширюється на його територіальні і внутрішні морські води.

Частіше зустрічаються посилання в документах внутрішньодержавного характеру. 3 цього приводу Г. Верле пише: «Акти національного законодавства, будучи відображенням як орinio јuris, так і практики держав, також можуть здійснити вплив на міжнародне кримінальне право - наприклад, через сприйняття міжнародних кримінально-правових норм в акті національного законодавства, такого як (Германський) Кодекс злочинів проти міжнародного права від 26 червня 2002 року» 27.

Для застосування норм національного законодавства в якості джерела транснаціонального кримінального права вимагається приведення національних законів у відповідність до міжнародних правових актів. При цьому посилання на специфіку кримінально-правової системи не можуть слугувати підставою для відмови держави від взятих на себе зобов'язань в силу відомого принципу «договори повинні виконуватися». Глобально цілі і завдання національного й міжнародного кримінального права збігаються: переслідування і покарання винних у скоєнні злочинів осіб, попередження злочинів, усунення причин і умов скоєння злочинів.

3 огляду на тісний зв'язок, що існує між транснаціональним кримінальним правом та національним правом (визнання злочином діяння, забороненого кримінальним законом не менше ніж двох держав, i обов’язок криміналізації транснаціональних злочинів та їх пеналізації; встановлення кримінальної відповідальності й віку, з якого настає відповідальність за конкретний злочин у внутрішньому праві та ін.), визнання національного законодавства джерелом транснаціонального кримінального права уявляється необхідним через закріплення відповідних норм у міжнародно-правових актах. Особи підпадають під кримінальну відповідальність тільки в тому випадку, якщо відповідна кримінально-правова заборона міститься в національному законодавстві (подвійна кримінальність), адже безпосередньо відповідальність накладається не міжнародним судом, а національним, при цьому можливий міжнародний контроль, зокрема Конвенція ООН 2000 р. (ст. 32) покладає контроль за «сприяння виконанню цієї Конвенції і проведення спостереження за ходом ії виконання» на Конференцію учасників Конвенції.

Висновки. Транснаціональне кримінальне право володіє власною системою джерел, яка є складовою системи джерел міжнародного кримінального права. Норми джерел цих систем тісно пов'язані між собою, містяться в міжнародно-правових актах універсального та регіонального характеру, серед яких вагоме місце 
посідають конвенції, зокрема Конвенція ООН проти транснаціональної організованої злочинності від 15 листопада 2000 року.

Серед джерел транснаціонального кримінального права слід виокремити особливе місце національного законодавства, яке в системі джерел міжнародного кримінального права належить до групи допоміжних джерел. Національне законодавство безпосередньо не регулює міжнародні відносини, проте впливає на транснаціональне кримінальне право різними шляхами, зокрема в національному законодавстві відбувається криміналізація транснаціональних злочинів, їх пеналізація, кримінальне переслідування, реалізація норм відповідно до визначеної в законодавстві юрисдикції тощо. Форми впливу національного законодавства на транснаціональне кримінальне право можуть бути різноманітними і виявлятися у визначенні національної кримінальної політики; при підписанні, ратифікації чи денонсації міжнародних конвенцій; при наданні правової допомоги державам та міжнародним організаціям тощо. Національні закони та інші нормативно-правові акти можуть стимулювати ухвалення нових чи внесення відповідних змін до інших міжнародно-правових документів, що в свою чергу сприяє поглибленню співробітництва держав у сфері протидії міжнародній злочинності в реалізації спільних інтересів світового співтовариства на основі загальних, визнаних цивілізованими націями, принципів права.

${ }^{1}$ Київець О.В. Джерела міжнародного права: дис. ... д-ра юрид. наук: 12.00.11 / Ін-т законодавства Верховної Ради України. Київ, 2012. 460 с.

2 Козюбра М.І. Тенденції розвитку джерел права України в контексті європейських правоінтеграційних процесів. Наукові записки Національного університету «Києво-Могилянська Академія». Юридичні науки. 2004. Т. 26. С. 3-9.

${ }^{3}$ Міжнародне публічне право: підручник: у 2-х т. / В.В. Мицик, М.В. Буроменський, М.М. Гнатовський та ін.; за заг. ред. В.В. Мицика. Харків: Право, 2019. Т. 1: Основи теорії. 416 с.

4 Пархоменко Н.М. Джерела права: проблеми теорії та методології: монографія. Київ: ТОВ «Видавництво «Юридична думка», 2008. 336 c.

5 Луць Л. Система джерел права: загальнотеоретична характеристика. Проблеми держсвотворення $і$ захисту прав людини в Україні: матеріали XIII регіональної наук.-практ. конференції, 8-9 лютого 2007 р. Львів: Юридичний факультет Львівського національного університету імені Івана Франка, 2007. 629 с. С. 44-46.

6 Статут Організації Об'єднаних Націй і Статут Міжнародного Суду ООН; Міжнародний документ від 26.06 .1945 р. URL: http://zakon5.rada.gov.ua/laws/show/995_010

${ }^{7}$ Міжнародне публічне право: підручник: у 2-х т. / В.В. Мицик, М.В. Буроменський, М.М. Гнатовський та ін.; за заг. ред. В.В. Мицика. Харків: Право, 2019. Т. 1: Основи теорії. 416 с.

8 Теорія та практика міжнародного кримінального права: підручник / Зелінська Н.А., Андрейченко С.С., Дрьоміна-Волок Н.В., Коваль Д.О.; за ред. проф. Зелінської Н.А. Одеса: Фенікс, 2017. 582 с.

${ }^{9}$ Friedman W. The Changing Structure of International Law. University Presses of California, Columbia and Princeton. January, 1966. $410 \mathrm{p}$.

10 Римський статут Міжнародного кримінального суду від 17.07.1998 p. URL: http://zakon5.rada.gov.ua/laws/show/995_588

11 Верле Герхард. Принципы международного уголовного права: учебник / пер. с англ. С.В. Саяпина. Одеса: Фенікс; Москва: ТрансЛит, 2011. 910 с

12 Каламкарян Р.А., Мигачев Ю.И. Международная нормативная система как институционно-правовая составляющая современного миропорядка. Государство и право. 2015. № 6. С. 62-70.

13 Лукашук И.И. Международное право: Особенная часть: учебник. 3-е изд., перераб. и доп. Москва: Волтерс Клувер, 2007. C. 421

${ }^{14}$ Ершов В.В. Универсальное в национальном и международном праве. Журнал российского права. 2018. № 7. С. 46-61.

15 Панов В.П. Международное уголовное право: учеб. пособ. Москва: Инфра-М, 1997. 320 с. С. 26.

16 Лукашук И.И. Нормы международного права в международной нормативной системе / ред. В.А. Качанов. Москва: Спарк, 1997. 322 с.

17 Ушаков Н.А. Международное право: учебник / Институт государства и права РАН. Москва: Юрист, 2003. 302 с. С. 27.

18 Кибальник А.Г., Соломоненко И.Г. Источники и система международного уголовного права. Государство и право. 2004. № 1. C. 62-67.

19 Блищенко И.П., Дориа Ж. Прецеденты в международном публичном и частном праве. 2-е изд., доп. Москва: Изд-во МНИМП, 1999. 472 с. С. $280-285$.

20 Иногамова-Хегай Л. Источники международного уголовного права. Общепризнанные приниипы и нормы международного права, международные договоры в практике конституционного правосудия: материалы Всероссийского совещания (Москва, 24 декабря 2002 г.) / под ред. М.А. Митюкова, С.В. Кабышева, В.К. Бобровой и А.В. Сычевой. Москва: Международные отношения, 2004. 536 с. С. 417-428.

21 Загальна теорія права: підручник / за заг. ред. М.І. Козюбри. Київ: Ваіте, 2015. 392 с. С. 353.

22 Теорія та практика міжнародного кримінального права: підручник / Зелінська Н.А., Андрейченко С.С., ДрьомінаВолок Н.В., Коваль Д.О.; за ред. проф. Зелінської Н.А. Одеса: Фенікс, 2017. 582 с.

23 Верле Герхард. Принципы международного уголовного права: учебник / пер. с англ. С.В. Саяпина. Одеса: Фенікс; Москва: ТрансЛит, 2011.910 с.

24 Про ратифікацію Конвенції Організації Об'єднаних Націй проти транснаціональної організованої злочинності та протоколів, що її доповнюють: Закон України від 4 лютого 2004 р. № 1433-IV. URL: https://zakon.rada.gov.ua/laws/show/1433-15

25 Конвенція Організації Об'єднаних Націй про боротьбу проти незаконного обігу наркотичних засобів і психотропних речовин від 20 грудня 1988 p. URL: https://zakon.rada.gov.ua/laws/show/995_096

26 Конвенція Організації Об'єднаних Націй проти транснаціональної організованої злочинності, ухвалена Резолюцією 55/25 Генеральної Асамблеї від 15 листопада 2000 p. URL: http://zakon.rada.gov.ua/laws/show/995_789

27 Верле Герхард. Принципы международного уголовного права: учебник / пер. с англ. С.В. Саяпина. Одеса: Фенікс; Москва: ТрансЛит, 2011. 910 с 
Резюме

Попко В.В. Національне законодавство - джерело транснаціонального кримінального права.

У статті розглядається національне законодавство у якості джерела (форми) транснаціонального кримінального права. Автор аналізує позиції вітчизняних та зарубіжних вчених щодо визнання національного законодавства в якості джерела міжнародного кримінального права. Визначається місце національного законодавства в системі джерел транснаціонального кримінального права та обгрунтовується його допоміжний характер.

Автором обгрунтовується позиція визнання національного законодавства джерелом транснаціонального кримінального права 3 огляду на важливу концептуальну особливість цієї підгалузі права, яка виявляється у взаємодії транснаціонального (міжнародного) та внутрішньодержавного (національного) кримінального права. Транснаціональне кримінальне право як підгалузь міжнародного кримінального права входить у систему міжнародного права, базується на її принципах і тісно пов'язане 3 національним кримінальним правом.

Ключові слова: джерело права, національне законодавство, транснаціональне кримінальне право, транснаціональний злочин, конвенція.

\section{Резюме}

Попко В.В. Национальное законодательство - источник транснационального уголовного права.

В статье рассматривается национальное законодательство в качестве источника (формы) транснационального уголовного права. Автор анализирует позиции отечественных и зарубежных ученых относительно признания национального законодательства в качестве источника международного уголовного права. Определяется место национального законодательства в системе источников транснационального уголовного права и обосновывается его вспомогательный характер.

Автором обосновывается позиция признания национального законодательства источником транснационального уголовного права, исходя из важной концептуальной особенности этой подотрасли права, которая проявляется во взаимодействии транснационального (международного) и внутригосударственного (национального) уголовного права. Транснациональное уголовное право в значении подотрасли международного уголовного права входит в систему международного права, базируется на ее принципах и тесно связано с национальным уголовным правом.

Ключевые слова: источник права, национальное законодательство, транснациональное уголовное право, транснациональное преступление, конвенция.

\section{Summary}

Vadym Popko. National legislation as a source of transnational criminal law.

The article covers the topic of national legislation as a source (form) of transnational criminal law. International criminal law doctrine has examined different aspects of legal sources many times, but development and establishment of transnational criminal law creates a necessity of research with a view to substantiating the concept of transnational criminal law and researching the empiric basis: international legal act and legislatures of different states.

Author finds that the systems of legal sources are in a state of constant development and reassessment, which does not change the fact that domestic legislation always takes its place in such systems. The author analyzes the positions of domestic and foreign scientists on the recognition of national legislation as a source of international criminal law. The place of national legislation in the system of sources of transnational criminal law its ancillary character is determined.

The author substantiates the position of recognition of national legislation as a source of transnational criminal law in view of the important conceptual feature of this sub-branch of law, which is manifested in the interaction of transnational (international) and domestic (national) criminal law. Transnational criminal law as part of international criminal law is part of the system of international law, is based on its principles and closely linked to national criminal law.

The article notes that every national or international legal system contains a specific system of legal sources, determined within its demands which allows to distinguish the peculiarities of each separate system. National legislation holds a special place in any of such system of sources of international criminal law and belongs to the group of auxiliary sources. It is emphasized that national legislation does not directly regulate international relations, but does affect transnational criminal law in various ways, in particular by criminalizing transnational crimes and penalizing them; according to the rules of national law, criminal prosecution of criminals and implementation of norms in accordance with the jurisdiction defined in the national legislation, etc., takes place.

Key words: transnational criminal law, transnational crime, source of law, national law, convention. 